ISSN: 2302-8556

E-Jurnal Akuntansi Universitas Udayana

Vol.22.2. Februari (2018): 1141-1169

DOI: https://doi.org/10.24843/EJA.2018.v22.i02.p12

\title{
Pengaruh Konflik Peran dan Ketidakjelasan Peran Terhadap Kinerja Auditor dengan Emotional Quotient Sebagai Variabel Pemoderasi
}

\author{
Devy Kusuma Cendana ${ }^{1}$ \\ I Gusti Ngurah Agung Suaryana ${ }^{2}$
}

${ }^{1}$ Fakultas Ekonomi dan Bisnis Universitas Udayana (Unud), Bali, Indonesia email: devy.cendana@gmail.com/Telp: +62 81933096222

${ }^{2}$ Fakultas Ekonomi dan Bisnis Universitas Udayana (Unud), Bali, Indonesia

\begin{abstract}
ABSTRAK
Auditor sering dihadapkan oleh potensi konflik peran dan ketidakjelasan peran sehingga mempengaruhi kinerja auditor. Seseorang yang memiliki Emotional Quotient (EQ) yang baik dapat mengelola emosinya dengan baik sehingga lebih bisa mengendalikan diri sendiri apabila dihadapkan konflik peran dan ketidakjelasan peran dalam menjalankan tugas atau perannya sebagai auditor sehingga kinerja yang dihasilkan cenderung lebih baik. Penelitian ini bertujuan untuk membuktikan bukti empiris pengaruh konflik pera dan ketidakjelasan peran terhadap kinerja auditor serta peran emotional quotient dalam memoderasi pengaruh konflik peran dan ketidakjelasan peran terhadap kinerja auditor. Penelitian ini dilakukan di Kantor Akuntan Publik di Bali dengan metode survey menggunakan instrument kuesioner. Jumlah sampel sebesar 72 responden dengan menggunakan metode penentuan sampel jenuh, dan kuesioner yang dapat dianalisis sebesar 43 analisis ini menunjukan bahwa konflik peran berpengaruh negatif pada kinerja auditor, ketidakjelasan peran berpengaruh negatif pada kinerja auditor, emotional quotient memperlemah pengaruh konflik peran pada kinerja auditor, dan emotional quotient memperlemah pengaruh ketidakjelasan peran pada kinerja auditor.
\end{abstract}

Kata Kunci: Kinerja auditor, konflik peran, ketidakjelasan peran, emotional quotient

\footnotetext{
ABSTRACT

Auditors are often confronted by potential role conflict and vagueness of roles thus affecting auditor performance. A person who has a good Emotional Quotient (EQ) can manage his emotions well so that he can better control himself if faced with role conflict and unclear role in performing his duties or role as an auditor so that the resulting performance tends to be better. This study aims to prove empirical evidence of the influence of pera conflict and unclear role on the performance of auditors and the role of emotional quotient in moderating the influence of role conflict and unclear role on the performance of auditors. This research was conducted at Public Accounting Firm in Bali with survey method using questionnaire instrument. The sample size of 72 respondents using the method of determining the saturated samples, and the questionnaire that can be analyzed by 43 analysis shows that role conflict negatively affect the auditor's performance, unclear role negatively affect the auditor's performance, emotional quotient weaken the influence of role conflict on auditor performance, and emotional quotient weakens the influence of unclear role on the auditor's performance.

Keywords: Auditor performance, role conflict, role ambiguity, emotional quotient
} 


\section{PENDAHULUAN}

Seiring dengan perkembangan zaman, pemenuhan akan ketersediaan tenaga kerja dalam dunia industri dan bisnis kian beragam. Dewasa ini profesi sebagai akuntan publik merupakan salah satu profesi yang banyak diminati masyarakat. Salah satu contohnya yaitu audit, yang merupakan jasa profesi yang dilakukan oleh Kantor Akuntan Publik (KAP) dan dilaksanakan oleh seorang auditor yang sifatnya sebagai penyedia jasa pelayanan. Seorang akuntan publik dalam melakukan audit atas laporan keuangan tidak semata-mata bekerja untuk kepentingan kliennya, melainkan juga untuk pihak lain yang berkepentingan dalam laporan audit. Pada Kantor Akuntan Publik (KAP) dibutuhkan seorang auditor yang independent, dimana dia akan mengambil keputusan tidak berdasarkan kepentingan klien, pribadi, maupun pihak lainnya, melainkan dimana berdasarkan fakta dan bukti yang berhasil dikumpulkan selama penugasan (Hery, 2005). Kinerja auditor menjadi perhatian utama, baik bagi klien ataupun publik, dalam menilai hasil audit yang dilakukan (Zaenal Fanani et al., 2007). Pada saat menjalankan tugasnya, auditor sering dihadapkan oleh potensi konflik peran (role conflict) sehingga mempengaruhi kinerja auditor.

Role conflict adalah suatu konflik yang timbul karena mekanisme pengendalian birokratis organisasi tidak sesuai dengan norma, aturan, etika, dan kemandirian profesional. Efek potensial dari konflik peran sangatlah rawan, baik bagi individual maupun organisasi dalam pengertian konsekuensi emosional, seperti tekanan tinggi yang berhubungan dengan pekerjaan, kepuasan kerja, dan kinerja yang lebih rendah (Fanani et al., 2007). Konflik peran biasanya timbul 
karena adanya ketidakcocokkan permintaan yang ditujukan pada seseorang dari orang lain di dalam maupun luar organiasi (Fanani dkk., 2008). Konflik peran juga dapat muncul ketika auditor menerima beberapa perintah yang berbeda dan kesulitan untuk menyesuaikan berbagai peran yang dimiliki dalam waktu yang bersamaan. Seperti misalnya, tuntutan utama seorang auditor bersumber dari etika profesi akuntan sedangkan tuntutan lain bisa bersumber dari sistem pengendalian yang diterapkan dalam KAP (Lubis, 2011). Fanani dkk. (2007) memilki pendapat yang sama yaitu konflik peran muncul karena adanya ketidaksesuaian antara pengharapan yang disampaikan pada individual didalam organisasi dengan orang lain didalam dan diluar organisasi.

Faktor lain yang seringkali dihadapi oleh auditor dalam menjalankan tugasnya adalah ketidakjelasan peran. Ketidakjelasan peran adalah tidak adanya informasi yang memadai yang diperlukan seseorang untuk menjalankan perannya dengan cara yang memuaskan (Fanani dkk. 2008). Agustina (2009) menyatakan bahwa ketidakjelasan peran mengacu pada kurangnya kejelasan mengenai harapan-harapan pekerjaan, metoda-metoda untuk memenuhi harapan-harapan yang dikenal, dan/atau konsekuensi dari kinerja atau peranan tertentu. Individu yang mengalami ketidakjelasan peran akan mengalami kecemasan, menjadi lebih tidak puas, dan melakukan pekerjaan dengan kurang efektif dibandingkan individu lain sehingga menurunkan kinerja mereka (Fanani dkk. 2008). Tang dan Chang (2010), menyatakan bahwa ketidakjelasan peran yang tinggi dapat mengurangi kepercayaan diri seseorang dalam kemampuannya untuk bekerja dengan efektif. Beberapa penelitian telah meneliti mengenai kinerja auditor yang 
dipengaruhi oleh konflik peran dan ketidakpastian peran, tetapi hasilnya masih menunjukan inkonsistensi. Hasil penelitian Fanani dkk. (2008), Agustina (2009), Putra dan Ariyanto (2012), Maulana dkk. (2012), serta Ermawati dkk. (2014) mengungkapkan bahwa konflik peran berpengaruh pada kinerja auditor, karena konflik peran dapat menimbulkan rasa tidak nyaman dalam bekerja, dan bisa menurunkan motivasi kerja karena mempunyai dampak negatif terhadap perilaku individu seperti timbulnya ketegangan kerja, banyak terjadi perpindahan pekerja, penurunan kepuasan kerja sehingga dapat menurunkan kinerja auditor. Namun, penelitian Widyastuti dan Sumiati (2011), Santoso (2012), serta Gunawan dan Ramdan (2012) mengungkapkan bahwa konflik peran tidak berpengaruh pada kinerja auditor. Agustina (2009), Widyastuti dan Sumiati (2011), Santoso (2012), serta Gunawan dan Ramdan (2012) mengungkapkan bahwa ketidakjelasan peran berpengaruh negatif terhadap kinerja auditor, karena dengan adanya ketidakjelasan peran dalam suatu kantor atau perusahaan, dapat membuat kinerja auditor menjadi kurang optimal dalam menangani kliennya, sehingga dapat menurunkan kinerja seorang auditor. Sementara Fanani dkk. (2008), Putra dan Ariyanto (2012), serta Maulana dkk. (2012) mengungkapkan bahwa ketidakjelasanperan tidak berpengaruh terhadap kinerja auditor.

Govindarajan (1986) menyatakan bahwa perbedaan hasil penelitian tersebut dapat diselesaikan melalui pendekatan kontijensi (contingency approach). Hal ini dilakukan dengan memasukan variabel lain yang mungkin memengaruhi ketidakjelasan peran dan konflik peran dengan kinerja auditor. Maka dari itu, pada penelitian ini ditambahkan variabel moderasi yaitu emotional quotient, yang 
diduga memiliki pengaruh antara ketidakjelasan peran dan konflik peran dengan kinerja auditor.

Emotional Quotient (EQ) adalah kemampuan mengenali perasaan diri sendiri dan perasaan orang lain, memotivasi diri sendiri, serta mengelola emosi dengan baik pada diri sendiri dan dalam hubungan dengan orang lain. Kemampuan ini saling melengkapi dan berbeda dengan kemampuan akademik murni, yaitu kemampuan kogniktif murni yang diukur dengan Intellectual Quotient (Goleman, 2001:512). Pada kenyataannya, perlu diakui bahwa kecerdasan emosional memiliki peran yang sangat penting untuk mencapai kesuksesan di sekolah, tempat kerja, dan dalam berkomunikasi di lingkungan masyarakat (Surya, 2004). Suatu konflik yang muncul dalam suatu organisasi yang dikarenakan oleh seseorang yang bekerja tidak sesuai dengan norma, aturan, etika yang ada dan tingkat keprofesionalan yang lemah bisa disebut dengan konflik peran. Hal ini menimbulkan suatu kondisi, dimana jika terdapat dua perintah yang bertolakbelakang namun diterima secara bersamaan akan mengakibatkan, dalam pelaksanaannya, terabaikannya perintah yang lain.

Berdasarkan uraian di atas, peneliti termotivasi untuk melakukan penelitian ini karena pertama, dalam menjalankan tugasnya, auditor eksternal rentan menghadapi konflik peran dan ketidakjelasan peran yang dapat berakibat menurunkan kinerjanya. Kemampuan seorang auditor untuk mengatur emosinya merupakan salah satu hal yang harus menjadi perhatian utama bagi auditor eksternal, bukan hanya kemampuan intelektualnya saja, karena orang yang memiliki kecerdasan emosional yang tinggi mampu mengetahui dan menangani 
Devy Kusuma Cendana dan I Gusti Ngurah Agung Suaryana. Pengaruh...

perasaan mereka sendiri dengan baik, serta mampu membaca dan menghadapi perasaan orang lain dengan efektif. Peneliti berharap dengan adanya variabel EQ maka peneliti dapat berkontribusi untuk memperbaiki penelitian atau hasil penelitian agar lebih konsisten. Hal ini diharapkan dapat menjadi salah satu kunci untuk keluar dari tekanan tersebut sehingga auditor dapat memperbaiki kinerjanya ke depan.

Teori peran dan teori kinerja merupakan landasan teori yang digunakan dalam penelitian ini. Teori peran menggambarkan interaksi sosial dalam terminologi aktor-aktor yang bermain sesuai dengan apa yang ditetapkan oleh budaya. Pada teori ini, harapan-harapan peran merupakan pemahaman bersama yang menuntun individu untuk berperilaku dalam kehidupan sehari-hari (Mustofa, 2006). Amstrong dan Baron (1998:15) memberikan pengertian bahwa teori kinerja berbicara mengenai hasil pekerjaan yang mempunyai hubungan kuat dengan tujuan strategi organisasi, kepuasan konsumen dan memberikan kontribusi ekonomi.

Konflik peran adalah suatu konflik yang timbul karena mekanisme pengendalian birokrasi organisasi tidak sesuai dengan norma, aturan, etika dan kemandirian profesional. Kondisi tersebut biasanya terjadi karena adanya dua perintah yang berbeda yang diterima secara bersamaan dan pelaksanaan salah satu perintah saja akan mengakibatkan terabaikannya perintah yang lain (Fanani dkk., 2008). Konflik peran dapat menimbulkan rasa tidak nyaman dalam bekerja dan bisa menurunkan motivasi kerja karena mempunyai dampak negatif terhadap perilaku individu seperti timbulnya ketegangan kerja, banyak terjadi perpindahan 
pekerja, penurunan kepuasankerja sehingga bisa menurunkan kinerja auditor secara keseluruhan (Fanani dkk., 2008).

Hasil penelitian yang dilakukan oleh Agustina (2009), Putra dan Ariyanto (2012), Maulana dkk. (2012) menunjukan bahwa konflik peran memiliki pengaruh pada kinerja auditor, hasil penelitian tersebut mendukung hipotesis dalam penelitian ini. Penelitian selanjutnya yang memiliki hasil berbeda yaitu hasil penelitian yang dilakukan oleh Kristina (2014) dan Hendra (2012) yang menunjukan bahwa konflik peran tidak berpengaruh pada kinerja auditor. Auditor yang mengalami konflik peran dalam proses audit yang sedang dilakukan, maka auditor tersebut cenderung akan merasakan hal tidak nyaman saar bekerja dan akan berdampak pada kinerjanya yaitu kinerjanya akan mengalami suatu penurunan.

$\mathrm{H}_{1}$ : Konflik peran berpengaruh negatif pada kinerja auditor

Ketidakjelasan peran adalah tidak cukupnya informasi yang dimiliki serta tidak adanya arah dan kebijakan yang jelas, ketidakpastian tentang otoritas, kewajiban dan hubungan dengan lainnya dan ketidakpastian sangsi dan ganjaran terhadap perilaku yang dilakukan (Fanani dkk. 2008). Individu yang mengalami ketidakjelasan peran akan mengalami kecemasan dan menjadi lebih tidak puas dan melakukan pekerjaan dengan kurang efektif dengan individu lain sehingga menurunkan kinerja mereka.

Hasil penelitian yang dilakukan oleh Fanani dkk. (2008) yang menunjukkan bahwa ketidakjelasan peran berpengaruh negatif terhadap kinerja auditor. Individu dapat mengalami ketidakjelasan peran jika mereka merasa tidak adanya kejelasan 
sehubungan dengan ekspektasi pekerjaan, seperti kurangnya informasi yang diperlukan untuk menyelesaikan pekerjaan atau tidak memperoleh kejelasan mengenai tugas-tugas dari pekerjaannya. Hasil penelitian yang dilakukan oleh Santoso (2012), Gunawan dan Ramdan (2012) menunjukan hasil yang serupa yaitu ketidakpastian peran berpengaruh pada kinerja auditor.

$\mathrm{H}_{2}$ : Ketidakjelasan peran berpengaruh negatif pada kinerja auditor.

Konflik peran adalah suatu konflik yang timbul dari mekanisasi pengendalian birokratis organisasi tidak sesuai dengan norma, aturan, etika, dan kemandirian professional. Konflik peran dapat menimbulkan rasa tidak nyaman dalam bekerja dan bisa menurunkan motivasi kerja karena mempunyai dampak negatif terhadap perilaku individu, seperti timbulnya ketegangan kerja, banyaknya terjadi perpindahan, penurunan kepuasan kerja sehingga bisa menurunkan kinerja auditor secara keseluruhan (Zaenal Fanani dkk., 2007).

Penelitian yang dilakukan oleh Zaenal Fanani dkk. (2007) menunjukan bahwa struktur audit, konflik peran berpengaruh signifikan terhadap kinerja auditor. Hasil penelitian ini mendukung hasil penelitian yang dilakukan oleh Rapina (2008) yaitu konflik peran berhubungan negatif dengan kinerja. Berdasarkan pengertian tradisional, kecerdasan meliputi kemampuan membaca, menulis, dan berhitung yang merupakan keterampilan kata dan angka yang menjadi fokus di pendidikan formal (sekolah), dan sesungguhnya mengarahkan seseorang untuk mencapai sukses di bidang akademis. Keberhasilan hidup tidak hanya ini saja, pandangan baru yang berkembang mengatakan bahwa ada kecerdasan lain di luar kecerdasan intelektual (IQ), seperti bakat, ketajaman 
pengamatan sosial, hubungan sosial, kematangan emosional, dan lain-lain yang harus juga dikembangkan (Rissyo dan Nurna, 2006).

$\mathrm{H}_{3}$ : Emotional quotient mampu memperlemah pengaruh konflik peran pada kinerja auditor

Ketidakjelasan peran (role ambiguity) muncul karena tidak cukupnya informasi yang diperlukan untuk menyelesaikan tugas-tugas atau pekerjaan yang diberikan dengan cara yang memuaskan. Ketidakjelasan peran merupakan kesenjangan pemahaman, ketidakpastian, dan ketidakjelasan apa yang harus dilakukan seseorang individual dalam melakukan pekerjaannya. Penelitian yang dilakukan oleh Agustina (2001) menujukkan bahwa keberadaan kecerdasan emosional yang baik akan membuat seorang karyawan menampilkan kinerja dan hasil kerja yang lebih baik. Penelitian lainnya yang pernah dilakukan oleh Boyatzis (1999 dalam Fabiola, 2005) dan Chermiss (1998 dalam Fabiola, 2005) terhadap beberapa subjek penelitian dalam beberapa perusahaan maka hasil yang didapat menunjukan bahwa karyawan yang memiliki skor kecerdasan emosi yang tinggi akan menghasilkan kinerja yang lebih baik yang dapat dilihat dari bagaimana kualitas dan kuantitas yang diberikan karyawan tersebut terhadap perusahaan. Chermiss juga mengungkapkan bahwa walaupun seseorang tersebut memiliki kinerja yang cukup baik tapi apabila dia memiliki sifat yang tertutup dan tidak berinteraksi dengan orang lain secara baik maka kinerjanya tidak akan dapat berkembang.

Secara khusus, auditor membutuhkan EQ yang tinggi karena dalam lingkungan kerjanya auditor akan berinteraksi dengan orang banyak baik di dalam maupun di luar lingkungan kerja, karena dalam proses audit yang dilakukan oleh 
auditor memiiki potensi ketidakpastian peran yang menimbulkan rasa gelisah, tidak nyaman, dan berdampak negatif pada perilaku auditor maka dirasa perlu seorang auditor memiliki EQ. EQ dapat berperan penting dalam membentuk moral disiplin auditor dan mengatur emosi yang terdapat dalam individu auditor tersebut. Dalam dunia kerja auditor, berbagai masalah dan tantangan yang harus dihadapi seperti persaingan yang ketat, tuntutan tugas, suasana kerja yang tidak nyaman dan masalah hubungan dengan orang lain. Masalah ketidakpastian peran karena kurangnya informasi yang dimiliki oleh auditor tersebut dalam dunia kerja auditor bukanlah suatu hal yang hanya membutuhkan kemampuan intelektualnya, tetapi dalam menyelesaikan masalah tersebut kemampuan emosi atau kecerdasan emosi lebih banyak diperlukan. Apabila seorang auditor dapat menyelesaikan masalah ketidakpastian peran dalam dunia kerjanya dengan emosi yang stabil maka akan menghasilkan kinerja yang lebih baik pula.

$\mathrm{H}_{4}$ : Emotional quotient mampu memperlemah pengaruh ketidakpastian peran pada kinerja auditor

\section{METODE PENELITIAN}

Penelitian ini menggunakan pendekatan kuantitatif yang berbentuk asosiatif, yang meneliti mengenai pengaruh konflik peran, ketidakjelasan peran pada kinerja auditor dengan emotional quotient sebagai variabel pemoderasi dan menggunakan sumber data primer. Lokasi penelitian dalam penelitian ini dilakukan pada Kantor Akuntan Publik di Bali yang nama dan alamatnya tercantum di Directory Kantor Akuntan Publik. Objek penelitian dalam penelitian ini adalah kinerja auditor pada Kantor Akuntan Publik di Bali. Variabel yang digunakan dalam penilitian ini ada tiga jenis yaitu variabel bebas, variabel terikat, dan variabel moderasi. Variabel 
bebas dalam penelitian ini adalaah koflik peran dan ketidakjelasan pera. Variabel terikat adalah kinerja auditor dan variabel moderasinya adalah emotional quotient. Ketiga jenis variabel tersebut diukur menggunakan skala likert 5 point yaitu: nilai $1=$ sangat tidak setuju, $2=$ tidak setuju, $3=$ netral, $4=$ setuju, $5=$ sangat setuju .

Populasi dari penelitian ini berjumlah 72 orang dengan teknik pengambilan sampel yang digunakan adalah sampling jenuh, sehingga semua populasi menjadi sampel. Teknik analisis data yang digunakan dalam penelitian ini adalah Moderated Regression Analysis (MRA), berdasarkan hasil moderated regression analysis dapat diamati dengan uji koefisien determinasi, uji $\mathrm{F}$ dan disertai uji t. Uji interaksi atau Moderated Regression Analysis (MRA) dapat dihitung dengan persamaan sebagai berikut.

$$
\mathrm{KA}=\alpha+\beta_{1} \mathrm{KFP}+\beta_{2} \mathrm{KTP}+\beta_{3} \mathrm{EQ}+\beta_{4} \mathrm{KFP} . \mathrm{EQ}+\beta_{5} \mathrm{KTP} . \mathrm{EQ}+\mathrm{e}
$$

Keterangan:

$$
\begin{aligned}
\text { KTP } & \text { Ketidakjelasan Peran } \\
\text { EQ } & =\text { Emotional Quotient } \\
{[\text { KFP.EQ] }=} & \text { Nilai Absolut antara KFP dan EQ yang mewakili Interaksi antara } \\
& \text { Konflik Peran dengan Emotional Quotient } \\
\text { [KTP.EQ] = } & \text { Nilai Absolut antara KTP dan EQ yang mewakili Interaksi antara } \\
& \text { Ketidakjelasan Peran dengan Emotional Quotient } \\
= & \text { Error }
\end{aligned}
$$

\section{HASIL DAN PEMBAHASAN}

Kuisiner pada penelitian ini disebarkan di tujuh KAP di Provinsi Bali. Kuesioner yang disebar sebanyak 72 kuesioner dan hanya 43 kuesioner yang kembali dan dapat digunakan, sedangkan sebanyak 29 kuesioner yang tidak dapat digunakan. KAP Drs. Ida Bagus Djagera sudah tidak beroperasi sehingga tidak dapat berpartisipasi dan peneliti tidak menyebarkan kuesioner ke KAP Drs. Ida Bagus Djagera, satu KAP yang sudah tidak beroperasi di wilayah Bali, lalu pindah ke 
Jakarta yaitu KAP Rama Wendra (Cab) serta terdapat satu KAP yang tidak dapat ikut berpartisipasi dalam penelitian ini dikarenakan kesibukan auditor dalam KAP tersebut yaitu KAP Sri Marmo Djogosarkoro dan Rekan, sedangkan di Kantor Akuntan Publik lainnya auditor sibuk dengan deadline penyelesaian proses audit dan turun ke klien, sehingga tidak bisa mengisi kuesioner.

Hasil statistik deskriptif pada Tabel 1 menujukkan bahwa nilai terendah (minimum) dari jumlah skor jawaban responden untuk variabel kinerja auditor (Y) sebesar 9,11 dan nilai tertinggi (maximum) sebesar 27,28. Nilai tengah (mean) dari jumlah skor jawaban responden untuk variabel kinerja auditor sebesar 24,3974, apabila dibagi 7 pertanyaan akan menghasilkan nilai sebesar 3,49 yang berada dikisaran 3,40 - 4,20 yang berarti kinerja auditor memiliki kriteria tinggi. Nilai deviasi standar dari variabel pengalaman auditor sebesar 4,20. Hal ini menunjukkan bahwa sebaran data condong ke kanan tetapi masih dalam batas normal.

Tabel 1.

Hasil Analisis Statistik Deskriptif

\begin{tabular}{cllllll}
\hline No & Variabel & N & Min & Max & Mean & Std. Dev \\
\hline 1 & Y & 43 & 9,11 & 27,28 & 24,3974 & 4,20161 \\
2 & KFP & 43 & 5.00 & 18,31 & 8,0672 & 4,69848 \\
3 & KTP & 43 & 9.45 & 32.72 & 15,5807 & 4.67224 \\
4 & EQ & 43 & 37.70 & 68.86 & 54,1563 & 7.87756 \\
\hline
\end{tabular}

Sumber: Data diolah, 2016

Berdasarkan Tabel 1 dapat diketahui bahwa nilai terendah (minimum) dari jumlah skor jawaban responden untuk variabel koflik peran (KFP) sebesar 5.00 dan nilai tertinggi (maximum) sebesar 18,31. Nilai tengah (mean) dari jumlah skor jawaban responden untuk variabel konflik peran sebesar 8,0672, apabila dibagi 5 pertanyaan akan menghasilkan nilai sebesar 1,61 yang berada dikisaran 1,00-1,80 
yang berarti konflik peran memiliki kriteria sangat rendah. Berdasarkan Tabel 1 dapat diketahui bahwa nilai terendah (minimum) dari jumlah skor jawaban responden untuk variabel ketidakpatian peran (KTP) sebesar 9.45 dan nilai tertinggi (maximum) sebesar 32.72. Nilai tengah (mean) dari jumlah skor jawaban responden untuk variabel ketidakpastian peran sebesar 15,5807, apabila dibagi 6 pertanyaan akan menghasilkan nilai sebesar 2,60 yang berada dikisaran 1,80-2,60 yang berarti ketidakjelasan peran memiliki kriteria rendah.

Berdasarkan Tabel 1 dapat diketahui bahwa nilai terendah (minimum) dari jumlah skor jawaban responden untuk variabel pendeteksian kecurangan (EQ) sebesar 37.70 dan nilai tertinggi (maximum) sebesar 68.86. Nilai tengah (mean) dari jumlah skor jawaban responden untuk variabel emotional quotient sebesar 54,16, apabila dibagi 15 pertanyaan akan menghasilkan nilai sebesar 3,61 yang berada dikisaran 3,40-4,20 yang berarti emotional quotient memiliki kriteria tinggi.

Berdasarkan Tabel 1 dapat diketahui bahwa nilai terendah (minimum) dari jumlah skor jawaban responden untuk variabel pendeteksian kecurangan (EQ) sebesar 37.70 dan nilai tertinggi (maximum) sebesar 68.86. Nilai tengah (mean) dari jumlah skor jawaban responden untuk variabel emotional quotient sebesar 54,16, apabila dibagi 15 pertanyaan akan menghasilkan nilai sebesar 3,61 yang berada dikisaran 3,40-4,20 yang berarti emotional quotient memiliki kriteria tinggi. Nilai deviasi standar dari variabel pendeteksian kecurangan sebesar 7,88 hal ini menunjukkan bahwa sebaran data condong ke kanan tetapi masih dalam batas normal. 
Devy Kusuma Cendana dan I Gusti Ngurah Agung Suaryana. Pengaruh...

Pengujian selanjutnya adalah uji instrumen penelitian, yang terdiri dari uji validitas dan reliabilitas. Syarat minimum suatu kuesioner untuk memenuhi validitas adalah jika koefisien korelasi (r) hitung yang bernilai lebih besar dari $r$ tabel, yaitu di atas 0,30. Berdasarkan Tabel 2 menunjukan bahwa instrumen penelitian dari item-item pertanyaan konflik peran (KFP), ketidakpastian peran (KTP), emotional quotient (EQ), dan kinerja auditor (KA) adalah valid. Hal ini dikarenakan korelasi antara skor masing-masing pertanyaan dengan skor total besarnya diatas 0.30 .

Tabel 2.

Hasil Uji Validitas

\begin{tabular}{|c|c|c|c|c|}
\hline No & Variabel & $\begin{array}{c}\text { Kode } \\
\text { Instrumen }\end{array}$ & Nilai Pearson Correlation & Keterangan \\
\hline \multirow[t]{5}{*}{1} & Konflik Peran & KFP.1 & 0,915 & Valid \\
\hline & (KFP) & KFP.2 & 0,955 & Valid \\
\hline & & KFP.3 & 0,910 & Valid \\
\hline & & KFP.4 & 0,977 & Valid \\
\hline & & KFP.5 & 0,941 & Valid \\
\hline \multirow[t]{6}{*}{2} & Ketidakjelasan & KTP. 1 & 0,804 & Valid \\
\hline & Peran & КТР.2 & 0,893 & Valid \\
\hline & (KTP) & КТР.3 & 0,333 & Valid \\
\hline & & KTP.4 & 0,840 & Valid \\
\hline & & KTP.5 & 0,923 & Valid \\
\hline & & KTP.6 & 0,877 & Valid \\
\hline \multirow[t]{15}{*}{3} & Emotional Quotient & EQ.1 & 0,476 & Valid \\
\hline & (KTP) & EQ.2 & 0,501 & Valid \\
\hline & & EQ.3 & 0,529 & Valid \\
\hline & & EQ.4 & 0,461 & Valid \\
\hline & & EQ.5 & 0,403 & Valid \\
\hline & & EQ.6 & 0,510 & Valid \\
\hline & & EQ.7 & 0,409 & Valid \\
\hline & & EQ.8 & 0,651 & Valid \\
\hline & & EQ.9 & 0.634 & Valid \\
\hline & & EQ.10 & 0,614 & Valid \\
\hline & & EQ.11 & 0,657 & Valid \\
\hline & & EQ.12 & 0,539 & Valid \\
\hline & & EQ.13 & 0,419 & Valid \\
\hline & & EQ.14 & 0,674 & Valid \\
\hline & & EQ.15 & 0,734 & Valid \\
\hline
\end{tabular}




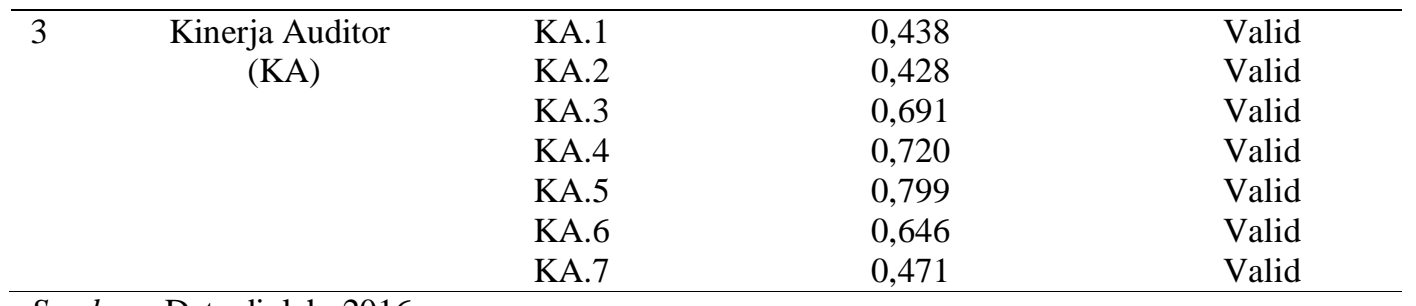

Sumber : Data diolah, 2016

Instrumen yang reliabel adalah instrumen yang digunakan beberapa kali untuk mengukur objek yang sama akan menghasilkan data atau jawaban yang sama pula. Pengujian ini dilakukan untuk menguji apakah data yang dikumpulkan melalui instrumen penelitian menunjukkan konsistensi internal yang memadai. Pada pengujian reliabilitas, apabila nilai crobach's alpha menghasilkan nilai alpha diatas 0,60, maka instrumen yang digunakan dikatakan reliabel. Berdasarkan Tabel 3 menunjukan bahwa nilai cronbach's alpha masing-masing variabel memiliki nilai lebih besar dari 0,60. Hal ini menunjukkan bahwa semua pertanyaan dalam kuesioner penelitian ini reliabel dan dapat digunakan.

Tabel 3.

Hasil Uji Reliabilitas

\begin{tabular}{llll}
\hline No & \multicolumn{1}{c}{ Variabel } & \multicolumn{1}{c}{$\begin{array}{c}\text { Cronbach's } \\
\text { Alpha }\end{array}$} & Keterangan \\
\hline 1 & Konflik Peran (KFP) & 0,966 & Reliabel \\
2 & Ketidakjelasan Peran (KTP) & 0,868 & Reliabel \\
3 & Emotional Quotient (EQ) & 0,808 & Reliabel \\
3 & Kinerja Auditor (KA) & 0,697 & Reliabel \\
\hline
\end{tabular}

Sumber: Data diolah, 2016

Penelitian ini menggunakan uji Kolmogorov-Smirnov untuk mendeteksi terpenuhi atau tidaknya uji normalitas dengan ketentuan bila tingkat signifikansi lebih besar dari atau sama dengan 0,05 maka berdistribusi normal. Berdasarkan Tabel 4 menunjukan bahwa nilai signifikansi sebesar $0,200>0,05$. Hal ini menunjukan bahwa model regresi berdistribusi normal. 
Tabel 4.

Hasil Uji Normalitas

\begin{tabular}{cc}
\hline Kolmogorov-Smirnov & Unstandardized Residual \\
\hline $\mathrm{N}$ & 43 \\
Asymp. Sig. (2-tailed) & 0,200 \\
\hline
\end{tabular}

Sumber: Data diolah, 2016

Nilai signifikansinya berada di atas 0,05 maka model regresi ini dapat

dikatakan bebas dari masalah heteroskedasitas. Hasil uji heteroskedastisitas disajikan pada Tabel 5. Berdasarkan Tabel 5 menunjukan bahwa nilai sig. dari masing-masing variabel adalah di atas 0,05 . Hal ini menunjukan bahwa seluruh variabel tersebut bebas dari heteroskedasitas.

Tabel 5.

Hasil Uji Heteroskedastisitas

\begin{tabular}{clcc}
\hline No & \multicolumn{1}{c}{ Variabel } & Sig. & Keterangan \\
\hline 1 & Konflik Peran (KFP) & 0,326 & Bebas Heteroskedasitas \\
2 & Ketidakjelasan Peran (KTP) & 0,447 & Bebas Heteroskedasitas \\
3 & Emotional Quotient (EQ) & 0,965 & Bebas Heteroskedasitas \\
3 & Konflik Peran* Emotional Quotient (KFP*EQ) & 0,332 & Bebas Heteroskedasitas \\
4 & Ketidakjelasan Peran* Emotional Quotient (KTP*EQ) & 0,498 & Bebas Heteroskedasitas
\end{tabular}

Sumber: Data diolah, 2016

Teknik analisis regresi linier berganda yang mengandung interaksi antar variabel independen atau Moderated Regression Analysis (MRA) digunakan dalam penelitian ini karena dalam penelitian mengandung uji interaksi. Hasil uji Moderated Regression Analysis (MRA) ditunjukan pada Tabel 6.

Tabel 6.

Hasil Moderated Regression Analysis

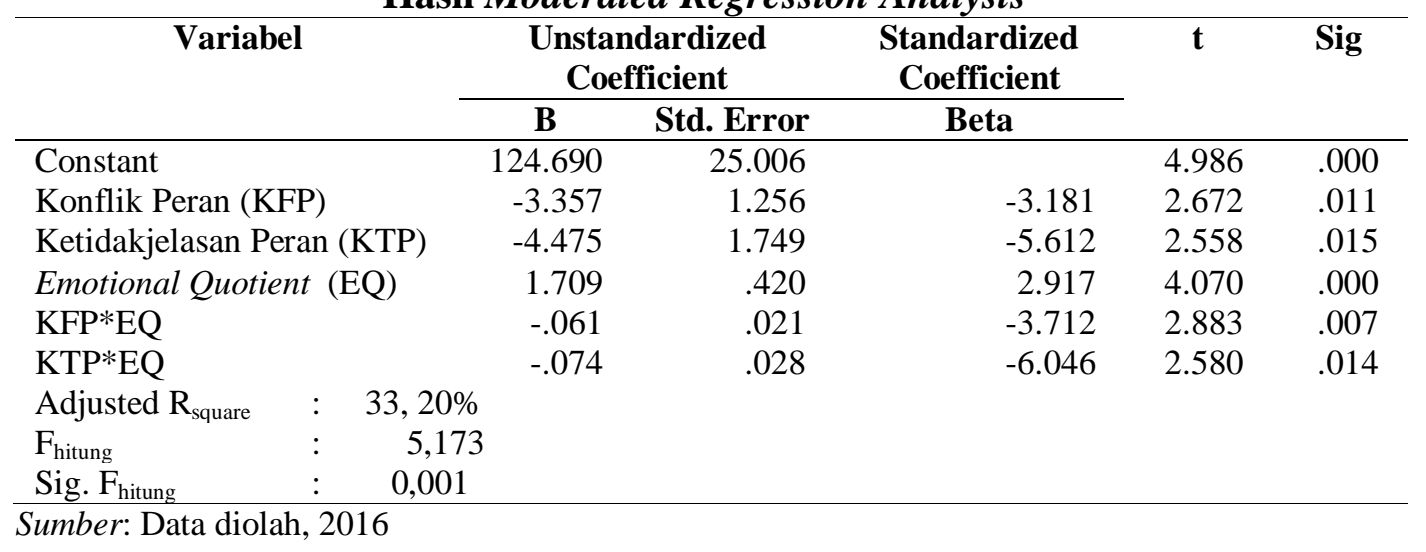


Berdasarkan Tabel 6 diatas, dapat dibuat persamaan regresi sebagai berikut.

$$
\mathrm{KA}=124,69-3,35 \mathrm{KFP}-4,47 \mathrm{KTP}+1.70 \mathrm{EQ}-0,06(\mathrm{KFP} * \mathrm{EQ})-0,07(\mathrm{KTP} * \mathrm{EQ})+\mathrm{e}
$$

Nilai konstanta sebesar 124,69 menunjukan bahwa nilai konflik peran (KFP) dan ketidakjelasan peran (KTP), emotional quotient (EQ) sama dengan nol, maka nilai kinerja auditor akan meningkat. Nilai koefisien regresi konflik peran $\left(\beta_{1}\right)$ sebesar -3,35 menunjukan bila konflik peran meningkat satu satuan, maka kinerja auditor cenderung mengalami suatu penurunan dengan asumsi variabel lainnya sama dengan nol. Nilai koefisien regresi ketidakjelasan peran $\left(\beta_{2}\right)$ sebesar - 4,47 menunjukan bila ketidakjelasan peran meningkat satu satuan, maka kinerja auditor cenderung mengalami suatu penurunan dengan asumsi variabel lainnya sama dengan nol.

Nilai koefisien regresi emotional quotient $\left(\beta_{3}\right)$ sebesar 1.70 menunjukan bila emotional quotient meningkat satu satuan, maka kinerja auditor cenderung akan mengalami suatu peningkatan dengan asumsi variabel lainnya sama dengan nol. Nilai koefisien moderat KFP. EQ $\left(\beta_{4}\right)$ sebesar $-0,06$ mengindikasi bahwa setiap interaksi antara konflik peran dan emotional quotient meningkat satu satuan, maka pengaruh konflik peran pada kinerja auditor cenderung akan mengalami suatu penurunan. Nilai koefisien moderat KTP. EQ $\left(\beta_{5}\right)$ sebesar $-0,074$ mengindikasi bahwa setiap interaksi antara ketidakjelasan peran dan emotional quotient meningkat satu satuan. Maka pengaruh ketidakjelasan peran pada kinerja auditor cenderung akan mengalami suatu penurunan. 
Devy Kusuma Cendana dan I Gusti Ngurah Agung Suaryana. Pengaruh...

Koefisien determinasi mengukur seberapa jauh kemampuan model dalam menerangkan variabel-variabel dependen. Berdasarkan Tabel 6 menunjukan bahwa besarnya adjusted $R^{2}$ adalah 0,332 . Hal ini menunjukan bahwa 33,20 persen variasi kinerja auditor dapat dijelaskan oleh variabel konflik peran, ketidakjelasan peran serta dimoderasi oleh variabel emotional quotient, sedangkan sisanya sebesar 66,80 persen dijelaskan oleh variabel lain di luar model.

Pengujian berikutnya adalah uji kelayakan model dengan uji F. Hasil analisis pada Tabel 6 menunjukan bahwa nilai F hitung sebesar 5,173 dengan nilai signifikan $\mathrm{F}$ atau $p$-value sebesar 0,000 yang lebih kecil dari nilai $\alpha=0,05$. Artinya variabel konflik peran, ketidakjelasan peran, interaksi antara konflik peran dengan emotional quotient, dan interaksi antara ketidakjelasan peran dengan emotional quotient secara bersama-sama (simultan) berpengaruh pada kinerja auditor.

Pengujian berikutnya adalah uji t yang dilakukan untuk melihat pengaruh variabel bebas terhadap variabel terikat secara parsial. Berdasarkan Tabel 6 menunjukan bahwa variabel konflik peran (KFP) memiliki koefisien regresi sebesar -3,357 dengan tingkat signifikansi sebesar 0,011. Angka sig t lebih kecil dari 0,05 yang berarti bahwa $\mathrm{H}_{0}$ ditolak dan $\mathrm{H}_{1}$ diterima. Koefesien regresi konflik peran memiliki tanda negatif, hal tersebut menunjukan bahwa semakin tinggi tingkat konflik peran pada auditor maka tingkat kinerja auditor cenderung akan mengalami penurunan.

Hasil penelitian ini konsisten dengan hasil penelitian yang ditemukan oleh Agustina (2009), Putra dan Ariyanto (2012), Maulana dkk. (2012) yang 
menunjukan bahwa konflik peran memiliki pengaruh negatif. Auditor yang mengalami konflik peran dalam proses audit yang sedang dilakukan, maka auditor tersebut cenderung akan merasakan hal tidak nyaman saar bekerja dan akan berdampak pada kinerjanya yaitu kinerjanya akan mengalami suatu penurunan.

Suwarto (1999) menyatakan konflik peran merupakan suatu konflik dihadapi oleh seseorang jika dua perangkat harapan atau lebih berlawanan satu sama lain, dan tuntutan peran berhubungan dengan tekanan pada seseorang sebagai suatu fungsi dari peran tertentu yang ia jalankan dalam organisasi. Robbins dan Judge (2009) menyatakan bahwa konflik peran meciptakan harapanharapan yang sulit untuk dipenuhi. Selain itu Hanny Yustrianthe (2008) juga menyatakan bahwa seseorang yang mengalami konflik peran maka akan menimbulkan suatu stress, dan apabila stres terjadi secara terus menerus dan berkepanjangan maka akan menyebabkan kinerja seseorang akan menurun.

Kesimpulannya adalah seorang auditor yang mengalami role conflict cenderung menimbulkan ketegangan psikologis yang berhubungan baik kesehatan mental maupun fisik sehingga dapat menimbulkan rasa tidak nyaman dalam bekerja dan bisa menurunkan motivasi kerja karena mempunyai dampak negatif terhadap perilaku individu, seperti timbulnya ketegangan kerja, banyaknya terjadi perpindahan, penurunan kepuasan kerja sehingga bisa menurunkan kinerja auditor.

Variabel ketidakpastian peran (KTP) memiliki koefisien regresi sebesar 4,475 dengan tingkat signifikansi sebesar 0,015. Angka sig t lebih kecil dari 0,05 yang berarti bahwa $\mathrm{H}_{0}$ ditolak dan $\mathrm{H}_{2}$ diterima. Koefesien regresi ketidakjelasan 
peran memiliki tanda negatif, hal tersebut menunjukan bahwa semakin tinggi tingkat ketidajelasan peran pada auditor maka tingkat kinerja auditor cenderung akan mengalami penurunan. Hasil penelitian ini konsisten dengan hasil penelitian yang ditemukan oleh Fanani et al (2008 Santoso (2012), dan Gunawan dan Ramdan (2012) menunjukan bahwa ketidakpastian peran berpengaruh negatif pada kinerja auditor.

Kreitner dan Kinicki (2007) menyatakan bahwa seseorang yang mengalami role ambiguity terjadi ketika mereka tidak mengetahui apa yang diharapkan darinya. Robbins dan Judge (2009) menyatakan bahwa role ambiguity terjadi ketika ekspektasi-ekspektasi peran tidak dipahami dengan jelas dan karyawan tidak yakin apa yang dilakukan. Seseorang dapat mengalami ketidakjelasan peran jika mereka merasa tidak adanya kejelasan sehubungan dengan ekspektasi pekerjaan, seperti kurangnya informasi yang diperlukan untuk menyelesaikan pekerjaan atau tidak memperoleh kejelasan mengenai tugas-tugas dari pekerjaannya. seseorang yang mengalami ketidakjelasan peran akan mengalami kecemasan dan menjadi lebih tidak puas dan melakukan pekerjaan dengan kurang efektif dengan individu lain sehingga menurunkan kinerja mereka. Kesimpulannya adalah auditor yang mengalami atau menghadapi ketidakjelasan peran dalam menjalankan perannya sebagai auditor maka auditor tersebut akan mengalami kecemasan, ketidakpuasan, serta kurang efektif dalam menjalankan tugasnya, oleh karena itu auditor yang mengalami ketidakjelasan peran akan cenderung mengalami penurunan kinerja. 
Variabel interaksi antara variabel konflik peran (KFP) dengan variabel emotional quotient (EQ) memiliki koefisien moderat sebesar -0,061 dengan tingkat signifikansi sebesar 0,007. Angka sig t lebih kecil dari 0,05 yang berarti bahwa $\mathrm{H}_{0}$ ditolak dan $\mathrm{H}_{3}$ diterima. Koefisien regresi konflik peran memiliki tanda negatif, hal tersebut menunjukan bahwa semakin tinggi tingkat konflik peran pada auditor maka kinerja auditor cenderung akan mengalami penurunan. Koefesien moderat interaksi antara konflik peran dan emotional quotient memiliki tanda negatif dengan signifikan nilai t yaitu lebih kecil dibandingkan nilai $\alpha$, hal tersebut menunjukan bahwa semakin tinggi interkasi antara konflik peran dengan emotional quotient, maka pengaruh konflik peran pada kinerja auditor akan semakin menurun. Hasil penelitian ini konsisten dengan hasil penelitian yang dilakukan oleh Reza Surya (2004), Rissyo dan Nurna (2006), Rapina (2008), dan Zaenal Fanani et al. (2007) dengan hasil penelitian yang menunjukan bahwa emotional quotient merupakan variabel moderating antara role conflict dan kinerja auditor.

Puspa dan Rianto (1999), konflik peran tidak akan timbul apabila seorang profesional yang bekerja dalam suatu organisasi mampu beradaptasi dengan lingkungan pengendalian organisasi di mana ia bekerja. Apabila hal ini diimbangi dengan emotional quotient, karena emotional quotient dapat membantu kinerja auditor disaat auditor dihadapkan tekanan dan tuntutan yang diberikan oleh peranperan yang dimiliki auditor dalam meningkatkan kinerjanya (Rahmawati, 2011). Kesimpulannya adalah seorang auditor yang memiliki kecerdasaan emosional dapat mengelola emosinya dan mengendalikan dirinya dengan baik, sehingga 
auditor dalam melaksanakan tugas auditnya mengalami suatu konflik peran dengan memiliki kecerdasan emosional yang baik maka seorang auditor tersebut dapat mengelola emosinya dengan baik sehingga dampak dari konflik peran seperti ketegangan kerja dan stres dapat diminimalisir sehingga kinerjanya lebih baik, dibandingkan seorang auditor yang tidak memeiliki kecerdasaan emosional.

Variabel interaksi antara variabel ketidakpastian peran (KTP) dengan variabel emotional quotient (EQ) memiliki koefisien moderat sebesar -0,074 dengan tingkat signifikansi sebesar 0,014. Angka sig t lebih kecil dari 0,05 yang berarti bahwa $\mathrm{H}_{0}$ ditolak dan $\mathrm{H}_{4}$ diterima. Koefisien regresi ketidakjelasan peran memiliki tanda negatif, hal tersebut menunjukan bahwa semakin tinggi ketidakjelasan peran pada auditor maka kinerja auditor cenderung akan mengalami penurunan. Koefesien moderat interaksi antara ketidakjelasan peran dan emotional quotient memiliki tanda negatif dengan signifikan nilai t yaitu lebih kecil dibandingkan nilai $\alpha$, hal tersebut menunjukan bahwa semakin tinggi interkasi antara ketidakjelasan peran dengan emotional quotient, maka pengaruh ketidakjelasan peran pada kinerja auditor akan semakin menurun. Hasil penelitian ini konsisten dengan hasil Fabiola (2005) berpendapat bahwa kecerdasan emosi adalah kemampuan di bidang emosi yaitu kesanggupan menghadapi frustasi, kemampuan mengendalikan emosi, semangat optimisme, dan kemampuan menjalin hubungan dengan orang lain atau empati. Hal tersebut seperti yang dikemukakan Patton (1998 dalam Fabiola, 2005) bahwa penggunaan emosi yang efektif akan dapat mencapai tujuan dalam membangun hubungan yang produktif dalam meraih keberhasilan kerja. Kinerja tidak hanya dilihat oleh faktor 
intelektualnya saja tetapi juga ditentukan oleh faktor emosinya. Seseorang yang dapat mengontrol emosinya dengan baik maka akan dapat menghasilkan kinerja yang baik pula. Hal ini sesuai dengan yang diungkapkan oleh Meyer (2004) dalam Fabiola (2005) bahwa kecerdasan emosi merupakan faktor yang sama pentingnya dengan kombinasi kemampuan teknis dan analisis untuk menghasilkan kinerja yang optimal. Salah satu aspek dalam kecerdasan emosi adalah motivasi. Goleman (2000) seperti yang dijelaskan sebelumnya, memotivasi diri sendiri merupakan landasan keberhasilan dan terwujudnya kinerja yang tinggi di segala bidang.

Kesimpulannya adalah auditor membutuhkan EQ yang cukup baik karena dalam lingkungan kerjanya auditor akan berinteraksi dengan orang banyak baik di dalam maupun di luar lingkungan kerja, karena dalam proses audit yang dilakukan oleh auditor memiiki potensi ketidakjelasan peran yang menimbulkan rasa gelisah, tidak nyaman, dan berdampak negatif pada perilaku auditor maka dirasa perlu seorang auditor memiliki EQ. EQ dapat berperan penting dalam membentuk moral disiplin auditor dan mengatur emosi yang terdapat dalam individu auditor tersebut. Masalah ketidakjelasan peran karena kurangnya informasi yang dimiliki oleh auditor tersebut dalam dunia kerja auditor bukanlah suatu hal yang hanya membutuhkan kemampuan intelektualnya, tetapi dalam menyelesaikan masalah tersebut kemampuan emosi atau kecerdasan emosi lebih banyak diperlukan. Seorang auditor dapat menyelesaikan masalah ketidajelasan peran dalam dunia kerjanya dengan emosi yang stabil maka akan menghasilkan kinerja yang lebih 
baik pula. Hasil ini menujukkan semakin baik kondisi emosional seorang auditor, maka kinerja yang akan mereka hasilkan akan semakin baik pula.

\section{SIMPULAN}

Berdasarkann hasil analisis maka dapat disimpulkan bahwa konflik peran berpengaruh negatif pada kinerja auditor. Artinya, semakin tinggi tingkat konflik peran yang dimiliki oleh seorang auditor maka kinerja auditor cenderung akan menurun. Ketidakjelasan peran berpengaruh negatif pada kinerja auditor. Artinya, semakin tinggi tingkat ketidakjelasan peran yang dimiliki seorang auditor maka kinerja auditor cenderung menurun. Emotional quotient memperlemah pengaruh konflik peran pada kinerja auditor. Semakin tinggi emotional quotient seorang auditor yang mengalami konflik peran maka kinerjanya cenderung akan meningkat, karena seorang yang auditor yang mengalami emotional quotient yang baik cenderung dapat mengelola atau mengatur emosinya dengan baik, sehingga dampak dari konflik peran yang dialami auditor yang mempengaruhi kinerjanya dapat diminimalisir sehingga dapat meningkat kinerjanya.

Emotional quotient memperlemah pengaruh ketidakjelasan peran pada kinerja auditor. Hasil ini menunjukkan bahwa semakin tinggi emotional quotient seorang auditor yang mengalami ketidakjelasan peran maka kinerjanya cenderung akan meningkat, karena emotional quotient dapat berperan penting dalam membentuk moral disiplin auditor dan mengatur emosi yang terdapat dalam individu auditor tersebut. Oleh karena itu seorang auditor yang mengalami ketidakjelasan peran dalam menjalankan tugasnya sebagai auditor dan mengalami ketegangan kerja, stress kerja, motivasi kerja yang menurun dan berdampak pada 
kinerjanya yang akan menurun, dengan memiliki emotional quotient yang baik dapat mengurangi dampak yang ditimbulkan akibat ketidakjelasan peran sehingga kinerja yang dihasilkan akan semakin baik atau meningkat.

Saran yang dapat diberikan dari hasil penelitian adalah bagi auditor khususnya di Kantor Akuntan Publik di Bali disarankan untuk agar lebih bisa meningkatkan emotional quotient atau kecerdasan emosional lebih baik, dengan emotional quotient yang baik maka dampak yang ditimbulkan oleh konflik peran dan ketidakjelasan peran dapat diminimalisir, sehingga meningkatkan kinerja auditor.

\section{REFERENSI}

Abdullah, Ma'ruf. 2014. Manajemen dan Evaluasi Kinerja Karyawan. Aswaja Pressindo. Yogyakarta.

Armstrong, Michael \& Baron, A. 1998. Performance Management : The New Realities, Institute of Personnel and Development, New York

Ahmad, Z., dan D. Taylor. 2009. Commitment to Independence by Internal Auditor: The Effects of Role Ambiguity and Role Conflict. Managerial Auditing Journal, 24(9): pp: 899-925.

Agustina, Lidya. 2009. Pengaruh Konflik Peran, Ketidakjelasan Peran, dan Kelebihan Peran terhadap Kepuasan Kerja dan Kinerja Auditor. Penelitian Kantor Akuntan Publik yang Bermitra Dengan Kantor Akuntan Publik Big Four di Wilayah DKI Jakarta. Univ.Kristen Maranatha. Jurnal Akuntansi. 1(1): h: 40-69 .

Amilin dan Rosita Dewi. 2008. Pengaruh Komitmen Organisasi terhadap Kepuasan Kerja Akuntan Publik dengan Role Stress sebagai Variabel Moderating. Jurnal Akuntansi \& Auditing Indonesia, 12(1): h: 13-24.

Anwar, Prabu Mangkunegara. 2005. Evaluasi Kinerja SDM, Cetakan Pertama, PT. Refika Aditama, Bandung.

Damajanti, A. 2003. Hubungan antara Mentoring dengan Ambiguitas Peran, Konflik Peran Kesan Ketidakpastian Lingkungan, Kinerja, dan Niat 
Pindah di Lingkungan Auditor Junior (Studi Kasus pada KAP di Indonesia). Tesis tidak dipublikasikan. Universitas Diponegoro Semarang.

Fanani, Zaenal., Hanif, A. R.., dan Subroto, B. 2008. Pengaruh Struktur Audit, Konflik Peran, dan Ketidakjelasan Peran terhadap Kinerja Auditor. Jurnal Akuntansi dan Keuangan Indonesia, h: 139-155.

Fried, Yitzhak, Ben-David, H. A., Tiegs, R. B., Avital, N., \& Yeverechyabu, U. 1998. The Interactive Effect of Role Conflict and Role Ambiguity on Job Performance. Journal of Occupational and Organizational Psychology 71, pp: 19-28.

Gibson, James L., John M. Ivancevich, James H. Donnelly, Jr., Robert Konopaske. 2006. Organizations, Behavior Structure Processes, Twelfth Edition, Mc Graw Hill, Singapore.

Goleman, Daniel. 2001. Emotional Intelligence-Kecerdasan Emosional, Gramedia, Jakarta.

Govindarajan, V. 1986. Impact of Participation in The Budgetary Process on Managerial Attitudes and Performance: Universalitic and Contigency Perspective. Decision Sciences 17: 496-516.

Gunawan, H. and Ramdan, Z. 2012. Pengaruh Konflik Peran, Ketidakjelasan Peran, Kelebihan Peran Dan Gaya Kepemimpinan Terhadap Kinerja Auditor Di KAP Wilayah DKI Jakarta. Jurnal Binus Business Review, $3(2)$.

Hanna, Elizabeth, dan Friska Firnanti. 2013. Faktor-Faktor yang Mempengaruhi Kinerja Auditor. Dalam Jurnal Bisnis dan Akuntansi, 15(1): h: 13-28.

Hendra. 2012. Pengaruh Konflik Peran, Ketidakjelasan Peran, Kelebihan Peran, dan Gaya Kepemimpinan Terhadap Kinerja Auditor di Kantor Akuntan Publik Wilayah DKI Jakarta. Skripsi. Universitas BINUS.

Hery. 2005. Etika Profesi dan Kepuasan Auditor. Media Akuntansi, Edisi 46/XII. Juni.

Jackson, Susan E. 1983. Participation in Decision Making as a Strategy for Reducing Job-Related Strain. Journal of Applied Psychology, 68(1): pp: 319.

Jones, Ambrose dan Carolyn Stand Norman Benson Wier. 2010. Healthy Lifestyle as a Coping Mechanism for Role Stress in Public Accounting. Behavioral Research In Accounting 22: pp:21-41. 
Kristina. 2014. Pengaruh Struktur Audit, Konflik Peran, Ketidakjelasan Peran dan Gaya Kempemimpinan Terhadap Kinerja Auditor. Skripsi. Universitas Muhamadiyah Surakarta.

Koo, Chi Mo and Ho Seog Sim. 1997. On the Role Conflict of Auditors in Korea, Accounting, Auditing, \& Accountability Journal, 12(2): pp: 206-219.

Kreitner, Robert and Angelo Kinicki. 2007. Organizational Behaviour. Seventh Edition Mc. Graw- Hill, International Edition, New York.

Lubis, Arfan Ikhsan. 2011. Akuntansi Keperilakuan. Edisi 2. Salemba Empat. Jakarta.

Maulana, Ichwan, Zirman, dan Alfiati Silfi. 2012. Pengaruh Struktur Audit, Konflik Peran, Ketidakjelasan Peran dan Locus of Control Terhadap Kinerja Auditor (Studi Empiris Pada Kantor Akuntan Publik di Pekanbaru dan Batam). Jurnal Jurusan Akuntansi Non Reguler Fakultas Ekonomi Universitas Riau.

Meirnayati, R. A. Fabiola. 2005. Analisis Pengaruh Kecerdasan Intelektual, Kecerdasan Emosi dan Kecerdasan Spiritual Terhadap Kinerja Karyawan. Tesis Program Pasca Sarjana. Universitas Diponegoro, Semarang.

Moheriono. 2012. Pengukuran Kinerja Berbasis Kinerja, Edisi Revisi. PT. Raja Grafindo Persada. Jakarta.

Mulyadi dan Kanaka Puradireja. 1998. Auditing. Buku ke-1. edisi kelima. Salemba Empat. Jakarta.

Mustofa, Hasan. 2006. Perspektif Dalam Psikologi Sosial. Makalah tidak dipublikasikan. Fakultas Administrasi Negara Universitas Parahiyangan Bandung.

Outley, David. 1980. The Contingency Theory of Management Accounting: Achievement and Prognosis. Accounting and Organization Society 5.

Pasolong, Harbani. 2008. Kepemimpinan Birokrasi. Bandung : Alfabeta

Putra, I Gede Bandar Wira dan Dodik Ariyanto. 2012. Pengaruh Independensi, Profesionalisme, Struktur Audit, dan Role Stress Terhadap Kinerja Auditor BPK RI Perwakilan Provinsi Bali. Jurnal Akuntansi. Universitas Udayana.

Rapina. 2008. Hubungan Supervisi, Tekanan Peran (Role Stress) dengan Kinerja dan Keinginan Berpindah pada Kantor Akuntan Publik di DKI Jakarta, Jurnal Ilmiah Akuntansi, 7(1): h: 40-70. 
Rahmawati dan Hanny Yustrianthe. 2008. Pengaruh Flexible Work Arrangement Terhadap Role conflict, Role Overload, Reduce Personal Accomplishment, Job Satisfaction dan Intention to Stay, Jurnal Bisnis dan Akuntansi, 10(3): h: 127-138.

Redfield, Robert, Ralph Linton and Melville, J. Herskovits. 1936. Memorandum for the Study of Acculturation. American Anthropologist. (1): pp: 149-152.

Rissyo Melandy RM dan Nurna Aziza. 2006. Pengaruh Kecerdasan Emosional Terhadap Tingkat Pemahaman Akuntansi, Kepercayaan Diri sebagai Variabel Pemoderasi. Simposium Nasional Akuntansi 9 Padang.

Rizzo, J.R., R.J. House, and S.I. Lirtzman. 1970. Role Conflict and Ambiguity in Complex Organizations, Administrative Science Quartely, 15(2): pp: 150163.

Robbins, Stephen P. and Timothy A. Judge. 2009. Organizational Behavior, Pearson International Edition, $13^{\text {th }}$ Edition, Upper Saddle River, New Jersey 07458.

Reza Surya. Pengaruh Emotional Quotient Auditor Terhadap Kinerja Auditor di Kantor Akuntan Publik, Perspektif: Jurnal Ekonomi Pembangunan, Manajemen, dan Akuntansi, 9(1): h: 33-40.

Sandy Martha, Muhamad. 2015. Karakteristik Pekerjaan dan Kinerja Dosen Luar Biasa UIN Sunan Gunung Djati Bandung: Komitmen Organisasi Sebagai Variabel Moderating. Tesis. Universitas Widyatama Bandung.

Sasono, Eko. 2004. Mengelola Stress Kerja. Fokus Ekonomi, 3(2): h: 121-128, 2004.

Sarwono, S.W. 2002. Teori-teori Psikologi Sosial. PT Raja Grafindo Persada. Balai Pustaka, Jakarta:

Surya, Reza dan Santosa Tri Hanato. 2004. Pengaruh Emotional Quetiont Auditor Terhadap Kinerja Auditor di Kantor Akuntan Publik. Perpektif, 9 (1): h: 33-40, Semarang.

Sri Trisnaningsih. 2007. Independensi Auditor dan Komitmen Organisasi Sebagai Mediasi Pengaruh Pemahaman Good Governance, Gaya Kepemimpinan, da Budaya Organisasi Terhadap Kinerja Auditor. Simposium Nasional Akuntansi $X$, Makasar.

Tang, Yung-Tai dan Chang, Cheng-Hua. 2010. Impact of Role Ambiguity and Role Conflict on Employee Creativity. African Journal of Business Management 4: pp: 869-881. 
Tsai, Ming Tien and Chia Mei Shis. 2005. The Influence of Organizational and Personal Ethic On Role Conflict Among Marketing Manager: An Empirical Investigation. Journal of Management International 22(1): pp: 54-62.

Widyastuti dan Sumiati. 2011. Influence of Role Conflict, Role Ambiguuity and Role Overload toward Auditors Performance. Jurnal Akuntabilitas 10(2): pp: 161-171.

Zaenal Fanani, Rheny Afriana Hanif, dan Bambang Subroto. 2007. Pengaruh Struktur Audit, Konflik Peran, dan Ketidakjelasan Peran Terhadap Kinerja Auditor. The 1st Accounting Conference, Faculty of Economics Universitas Indonesia, Depok. 